\title{
Situating Mindfulness, Part 1: Early Buddhism and Scientific Research in Psychology
}

\author{
Bhikkhu Anālayo ${ }^{1}$
}

Accepted: 15 June 2021 / Published online: 27 August 2021

(c) The Author(s) 2021

\begin{abstract}
As the first of three articles, the present essay explores the character of selected aspects of early Buddhism in order to assess its potential relevance as a reference point for those engaged in research on mindfulness in psychology. The exploration, which proceeds in critical dialog with suggestions made by Donald Lopez Jr. and Evan Thompson, covers the topics of the Buddha's omniscience, Buddhist cosmology, the notion of karma, the role of rebirth, the past lives of the Buddha, and the role of religious authority vis-à-vis the scope of personal investigation in early Buddhist thought. The present paper is meant to serve as a corrective to an apparent tendency in recent scholarship, as part of an in itself deserved criticism of exaggerated positions taken by Buddhist modernists, to overlook or even deny rational dimensions of Buddhist thought, here in particular taken up from the viewpoint of its earliest phase. This tendency appears at times to be based on a lack of historical perspective or understanding of Buddhist doctrines and their development.
\end{abstract}

Keywords Cosmology $\cdot$ Early Buddhism $\cdot$ Investigation $\cdot J a ̄ t a k a \cdot$ Karma $\cdot$ Omniscience $\cdot$ Oral Tradition $\cdot$ Rebirth Religious Authority · Science

The remarkable growth of the clinical employment of mindfulness inevitably has become part of an ongoing discussion (and at times debate) between "Buddhism" and "science," which has its own particular history and dynamics (Cabezón 2003). From the viewpoint of the clinical employment of mindfulness, a key question would be if the traditional religious setting of mindfulness should be considered just irrelevant baggage, better to be dropped as extraneous to clinical needs, or if an appreciation of the Buddhist framework can rather be of help and relevance for contextualizing, better understanding, and at time perhaps even reorienting mindfulness-based practices.

In order to explore this question, it needs to be recognized, first of all, that there is no monolithic entity to which the term "Buddhism" could justifiably be applied (the same also holds for the term "science"). Hence, there is a need to specify what type of Buddhism is being brought into the arena of discussion. Of particular relevance here would be the so-called "early Buddhism." This term stands for the

\section{Bhikkhu Anālayo}

1 Barre Center for Buddhist Studies, 149 Lockwood Road, Barre, MA 01005, USA reconstruction, based on text-critical comparative studies, of Buddhist thought approximately two centuries after the time when the historical Buddha would have lived and taught (Anālayo 2012). Given that the actual words of the Buddha, as a historical person, can no longer be reliably retrieved, such reconstruction is about as early a stage as possible still within the reach of scholarly study. This type of reconstruction attempts to discern between early and later layers of the teachings attributed to the Buddha, in the way these have been reported in the relevant textual sources, the "early discourses" delivered orally to an audience and formalized during the subsequent extended period of oral transmission. The teachings in these early discourses form the common starting point for the different Buddhist traditions still extant today, investing an exploration of this type of thought with a fairly broad general relevance.

As in ancient India writing was not employed for the purpose of transmitting religious teachings, the "texts" relevant to the reconstruction of early Buddhism are the final records of a long process of oral transmission. Now, an oral tradition is by its nature influenced by interaction with daily life experience on the ground. An oral text, resulting from an actual oral performance and then transmitted by relying on group recitation to diminish memory errors, is substantially 
different from the writing of the present article, for example, done by a single person and without a direct interaction with the target audience. The need to negotiate between a memorized text and the expectations and interests of the audience that forms the setting of an oral performance has impacted the early Buddhist oral tradition in various ways. As a result, a comparative study of different transmission lineages of the early discourses enables identifying such influences and discern behind them historical stages in the development of Buddhist thought and practices.

\section{Omniscience and Cosmology}

One development of considerable importance for an assessment of the nature of early Buddhist thought vis-à-vis scientific rationalism in general is the historically late attribution of omniscience to the Buddha (Anālayo 2006 2014, pp. 117-127, and 2020b, pp. 21-25). In its ancient Indian setting, such an attribution is easily understandable as an attempt to equal Mahāvīra, a contemporary of the Buddha and the leader of the Jains, who according to the relevant sources had indeed claimed to be omniscient. In view of the competition for lay support between Buddhist and Jain monastics, a wish to equal such a claim must soon have had its impact on conceptions of the nature and knowledge of the Buddha.

The basic difference between the Buddha and Mahāvīra in respect to actually claiming to be endowed with omniscience can be seen reflected in their documented teachings, where Mahāvīra is on record for offering a range of precise details on the nature of the world, revealing the comprehensive nature of his omniscient knowledge. From an early Buddhist perspective, in contrast, the emphasis is on "the world" as a construct of the senses (SN 1.70 and SA 1008 ; Anālayo 2021, p. 598). This forms part of a general interest in the construction of experience and the potential of mindfulness to become aware of the impact of such construction and possibly even step out of it (Anālayo 2019a).

Different dimensions of ancient Indian cosmology, taken over in the Buddhist traditions, can probably be better appreciated within the setting provided by such an orientation toward the construction of experience. An example in case is Mount Meru, whose basic ancient Indian conception as the central axis of a flat world is of course incompatible with scientific knowledge of the planet Earth. After surveying how Buddhist traditionalists have tried to deal with this contrast, Lopez (2008, p. 72) reasoned:

Once the process of deciding between the essential and the inessential is under way, it is often difficult to know where to stop. The question, then, is which Buddhist doctrines can be eliminated while allowing Buddhism to remain Buddhism. Can there be Buddhism without Mount Meru? Can you play chess without the queen?

In order to follow up this query, it can be useful to take a look at references to Mount Meru in Pāli discourses that have discourse parallels with similar teachings, having been transmitted by other reciter traditions. Two instances relevant to the present exploration refer to the eventual destruction of Mount Meru as an exemplification of impermanence (SN 22.99 and its parallel SĀ 266; AN 7.62 and its parallels MĀ 8, T 30, EĀ 40.1, and Dietz 2007). A third instance conveys basically the same teaching, based on describing a thousand world systems, each with their respective Mount Meru (AN 10.29 and its parallels MĀ 215 and Up 5011).

Such instances would fulfil their purpose just as well if they were to refer to Mount Himālaya instead of Mount Meru, as all that is required for the teaching to make its point is a large mountain known among the audience for its apparent stability. None of these instances implies a truth claim made by an omniscient teacher that the earth is flat and has a particular mountain as its axis. In terms of a game of chess, acknowledging that Mount Meru is not the central axis of a flat world would not even be comparable to the loss of a pawn, let alone the queen.

In general, the incorporation of this type of incontrovertible scientific knowledge creates no substantial problem as long as the Buddha is not invested with a claim to omniscience, as is often the case in later tradition. Hence, adopting a text-historical perspective on the attribution of omniscience to the Buddha is of considerable consequence. It is curious that this perspective is not taken into account by Lopez (2008, p. 4), who introduces his study, titled Buddhism \& Science, A Guide for the Perplexed, as follows: "I write as a historian of Buddhist thought and practice." This is particularly remarkable as he is evidently aware of Pāli discourse material documenting that, at an early stage in the history of Buddhist thought, the Buddha was not seen as having claimed to be omniscient (p. 65). The important perspective that emerges in this way would have merited an explicit discussion, beyond the brief remark that the various Buddhist traditions "are not univocal" on the nature of the Buddha's omniscience. As a historian writing a history of the idea that Buddhism and science are compatible, why not adopt a historical perspective on the Buddhist doctrinal positions that are of central relevance to that idea?

\section{Past Lives of the Buddha}

Adopting a historical perspective also offers an important tool for contextualizing other Buddhist ideas and evaluating to what extent these indeed stood at the very heart of the tradition from the outset. This requirement holds in relation 
to the statement by Lopez $(2008$, p. 8) that the Buddha has been portrayed "with a great consistency across the geographical and historical range of the tradition" as having cultivated the perfections "over the course of millions of lifetimes" and performed the twin miracle, a feat based on the ability "to rise into the air and simultaneously shoot forth fire and water from his body." The very idea that particular practices over several lifetimes lead to becoming a Buddha is a later element (Anālayo 2010a and 2017a). The perfections, in the sense of a set of qualities to be developed by a Buddha-to-be, are not mentioned at all in the Pāli discourses and their parallels. The same holds for the twin miracle; in fact, feats of physical levitation appear to be in themselves the result of literalism (Anālayo 2016a).

Comparative study shows that stories of past lifetimes of the Buddha are often the result of a literal interpretation of what originally was just a parable or fairy tale (Anālayo 2010a, pp. 55-71). An example already noted by Rhys Davids (1903/1997, p. 194) is a parable involving a quail and a hawk to illustrate an aspect of mindfulness practice (SN 47.6, which has a parallel in SĀ 617). In the Pāli Jātaka collection, the story has become a past life of the Buddha (Jā 168). At times, a story now found in the Pāli Jātaka collection appears to have originated in a non-Buddhist setting, as a result of which the main teaching conveyed can even be in conflict with Buddhist values (Anālayo 2016b). Such instances need to be evaluated by keeping in mind the way descriptions of the Buddha's former life experiences came into existence.

A need to contextualize information also holds for the occurrence of at times staggering numbers with reference to time spans or audiences, etc., found already in early Buddhist texts. As a feature shared with oral tradition in general, such numbers often have a symbolic nature and for this reason should not be read too literally. An example in case is the description of the potential of mindfulness practice, given in the Satipatțhana-sutta and its Madhyama$\bar{a}$ gama parallel (MN 10 and MĀ 98). The two versions agree that a practitioner can reach the higher two levels of awakening after a period of 7 years, followed by alternatively stipulating a period of $6,5,4,3,2$ years, or just 1 year. Continuing further, the two versions next mention 7 months, followed by counting down one by one until reaching a single month. This mode of presentation does not imply that these levels of awakening could not be reached after, say, 8 months. Instead, the presentation revolves around the symbolic nature of seven as representative of "a totality" (Dumont 1962, p. 73). Hence, it is natural to count down from seven to one for years and then do the same for months. The idea is simply that the results of mindfulness practice can take quite some time to ripen but can also manifest soon. The actual numbers given are only secondary to this meaning.
Seven times twelve, another symbolic number, and raised to the level of thousands, results in 84,000, a number that frequently occurs in Buddhist texts. One example is the depiction of a past life of the Buddha as the first in a series of 84,000 kings, each of which was endowed with a life span of many thousands of years (MN 83, MĀ 67, EĀ 50.4, and Up 2050). It would not be doing justice to the oral nature of these texts and the symbolic significance of numbers in the ancient setting if one were to start computations based on a literal reading, contrasting the time required for this succession of kings to take place to our knowledge of the evolution of species and the age of this planet.

In this way, keeping in mind the oral nature of the tradition as well as acknowledging that early Buddhism was a flourishing tradition without any need for the idea that the Buddha had cultivated the perfections over many lives or that he was able to perform the twin miracle, in terms of the game of chess these ideas would probably also amount to pawns. The same holds for the exaggerated numbers employed in this type of oral literature, which does not call for a literal reading, at least as long as the idea is to understand what such texts from a distant past and a different culture were probably meant to convey.

\section{Karma and Rebirth}

Unlike Mount Meru or the twin miracle, the notion of rebirth is a key element of early Buddhist thought, whose importance could reasonably be compared to the queen in a game of chess. This notion pervasively informs early Buddhist thought, including the affirmation that there are different realms of existence, some of which are inhabited by celestial beings. The principle of rebirth is also central in the conceptualization of different levels of spiritual progress until reaching full awakening, which in turn equals freedom from future rebirth.

The very idea of rebirth conflicts with a basic paradigm adopted in much of scientific research conducted in psychology, which relies on equating the mind with the brain. Although research that is based on this premise naturally tends to give the impression of confirming the adopted paradigm, in actual fact the equation itself has never been decisively proven. Moreover, a body of empirical facts can be quoted in support of the notion of rebirth (Anālayo 2018b). In short, as of now, rebirth has neither been decisively proven nor definitely disproven. Hence, the question of rebirth is not a clash of religious superstition with scientifically established truth, but much rather a matter of adopting different paradigms.

From an early Buddhist viewpoint, following the eightfold path of practice does not require accepting rebirth on blind faith (Anālayo 2018b, pp. 27-31, and 2019b). There is sufficient scope for personally taking an agnostic position 
on the matter. There is a need, however, to acknowledge the ubiquity of rebirth in early Buddhist discourse, without which a proper understanding of the type of teachings reflected in these texts is not really possible.

A central concept at the background of the notion of rebirth is karma, literally "action," which in its early Buddhist setting stands for the doctrinal affirmation that the ethical quality of the intentions motivating one's deeds will have repercussions to be experienced sooner or later, in the present or in future lives. According to Lopez (2008, p. 21), in "classical Buddhist doctrine, all human experiences of pleasure and pain are the result of deeds done in the past." In the context of a discussion of the second of the four noble truths, Lopez (p. 148) affirmed the same position, in that "all feelings of physical and mental pain are the result of deeds performed in the past."

Versions of an early discourse directly address this topic, reporting the Buddha's criticism of contemporary recluses and brahmins taking precisely the position that Donald Lopez attributed to classical Buddhist doctrine:

Those recluses and brahmins who hold such a doctrine and have such a view: "Whatever an individual person experiences, be it pleasant, or unpleasant, or neutral, all of it is due to former deeds," they go beyond personal experience and they go beyond what is acknowledged as true in the world. Therefore, I declare these recluses and brahmins to be in the wrong.

(SN 36.21: ye te samaṇabrāhmaṇa evamvāidino evamdițthino: yam kiñcāyam purisapuggalo pațisamvedeti sukham vā dukkham vā adukkhamasukham vā sabbam tạn pubbekatahetū ti. yañ ca sāmam ñātam tañ ca atidhāvanti yañ ca loke saccasammatam tañ ca atidhāvanti. tasmā tesam samaṇabrāhmaṇānam micchā ti vadāmī ti).

When those recluses and brahmins proclaim that everything that is known and felt by a person has its origin entirely in formerly created conditions, they have relinquished what is a matter of truth in the world and follow their own views; they make false statements. (SĀ 977: 若彼沙門婆羅門言, 一切人所知覺者, 皆 是本所造因, 捨世間真實事而隨自見; 作虛妄說; see also $S \bar{A}^{2} 211$, which makes the same basic point, although differing in formulation).

The Pāli version of the above discourse is quoted in the Milindapañha (Mil 137), reflecting a continuity of awareness of this position on the notion of karma. This goes to show that a correct reflection of the position taken in classical Buddhist doctrine is that a range of conditions can be responsible for "human experiences of pleasure and pain." What has been done previously is only one of these conditions. This corrective in turn puts into perspective the following reasoning by Lopez (2008, p. 148):

If the forms of life on earth, the animal and human species, are instead shown to be the result of evolution, of a process of natural selection, karma becomes superfluous and rebirth becomes impossible. Darwin's theory of evolution thus presents particular problems for Buddhism because it obviates the law of karma.

The proposed reasoning appears to result from the idea that karma functions as a monocausal principle. Yet, the early Buddhist teachings on causation eschew mono-causality, envisaging instead whatever happens as the result of a network of causes and conditions. Darwin's theory of evolution, therefore, does not obviate the law of karma. Instead, the law of karma can be visualized as operating within the framework provided by the evolution of species, in the sense that one's former deeds will influence one's rebirth among a particular one of the species extant at a particular time. Alternatively, one's former deeds may instead result in being reborn in another realm.

Given that Lopez (2008, p. 216) is concerned with the demands the rhetoric of scientific compatibility makes on traditional elements of premodern Buddhism, attempting to evaluate "what is at stake in their loss," would it not have been pertinent to this inquiry to try first of all to understand those elements appropriately? A confusion of the Buddhist position on karma with the tenets held by non-Buddhists in the ancient Indian setting is not a promising starting point for evaluating the significance of this doctrinal item in the dialog between "Buddhism" and "science."

\section{Authority and Investigation}

The topic of the Buddha's supposed omniscience is also taken up in a monograph titled Why I am not a Buddhist (inspired by an essay by Bertrand Russel titled "Why I am not a Christian"). The author Thompson (2020, p. 37) reasoned that "the cognition of a buddha is traditionally considered to be omniscient and infallible, and hence, his or her teaching is incontrovertible." The reference to omniscience as a traditional belief is at first sight unexpected, as Thompson (p. 20) identified the target of his exploration to be "European and American Buddhist modernism," which hardly exhibits much interest with the Buddha being omniscient. Here and elsewhere, it seems that the scope of the author's critical engagement goes beyond the specifically targeted group and for this reason is relevant to the present essays.

In the course of such a broader scope of exploration, Thompson (p. 39) expressed his assessment that, since "the 
Buddha is typically portrayed as omniscient and transcendent (supramundane) ... We need to place our faith in the Buddha (and a host of bodhisattvas) and not rely on our limited perspective and defective perception." Although this may in part explain the somewhat defiant attitude conveyed by the title chosen for his book, at least as far as the early Buddhist type of traditional perspective is concerned, the situation turns out to be different. Not only is the Buddha not yet considered omniscient; the qualification of being supramundane is also not applied to him. Faith or confidence in the Buddha concerns in particular his claim to have reached awakening (Anālayo 2017b, p. 227), an initial trust that serves as a natural requirement for being willing to follow his teachings in order to reach awakening oneself.

Those who have not yet awakened are indeed considered to have a "limited perspective and defective perception," as only arahants/arhats have eradicated the defilements that tend to distort perception and result in limited perspectives. Nevertheless, there is ample room for independent investigation even before deciding whether to become a disciple of the Buddha, let alone becoming an arahant. This can be seen in the Vimamsaka-sutta and its parallel (MN 47 and MĀ 186; Anālayo 2010b). The parallels report the Buddha openly inviting a prospective disciple to undertake the most searching scrutiny of his potential teacher, even to the extent of directly investigating the Buddha's claim to have reached awakening. Explicitly permitted modalities of investigation include close observation of the Buddha's behavior to see if it matches his claim just as much as questioning him face to face as to whether he is really free from defilements. This goes to show that, at least in early Buddhist thought, the scope of free inquiry was not limited even when this concerns the Buddha's role as a teacher. It would not be easy to find such an open encouragement of a similar type of free investigation, given by the founder of the tradition, in the canonical texts of other ancient Indian religious institutions.

A related attitude emerges from the report in another Pāli discourse and its parallels of a proposal made by the Buddha to a group of non-Buddhist wanderers, in which he is on record for offering them the option of putting his teachings into practice without needing to acknowledge him as their teacher.

Nigrodha, suppose it should then occur to you thus: "The recluse Gotama speaks like this desiring to get disciples." But, Nigrodha, this should not be seen in this way. Let whoever is your teacher remain your teacher. (DN 25: siya kho pana te, nigrodha, evam assa: antevāsikamyatā no samaṇo gotamo evam āhā ti. na kho pan' etam, nigrodha, evam datthabbam. yo eva vo àcariyo, so eva vo ācariyo hotu).
Do not say: "Is the Buddha teaching the Dharma for the sake of fame, for the sake of being respected, for the sake being the leader, for the sake of having followers, for the sake of having a great company?" Do not give rise to this thought! Your followers now completely belong to you while being taught by me the Dharma for the sake of eradicating what is unwholesome and increasing wholesome states.

(DĀ 8: 汝將無謂: 佛爲名稱, 爲尊重故, 爲導首故, 爲 眷屬故, 爲大眾故, 而說法耶? 勿起此心! 今汝眷屬 盡屬於汝, 我所說法, 爲滅不善, 增長善法).

Suppose you think like this: "The recluse Gotama teaches the Dharma because he wants to be the teacher!" Do not think like that; the [role of] the teacher remains yours while I am teaching the Dharma to you ... Suppose you think like this: 'The recluse Gotama teaches the Dharma because he wants disciples!' Do not think like that. The disciples remain yours while I am teaching the Dharma to you.

$(\mathrm{MA}$ 104: 若汝作是念: 沙門篗曇貪師故說法! 汝 莫作是念, 以師還汝, 我其爲汝說法 ... 若汝作是 念: 沙門篗曇貪弟子故說法! 汝莫作是念, 弟子還 汝, 我其爲汝說法; the corresponding part in a parallel extant as an individually translated discourse, $\mathrm{T} 11$, appears to have suffered from a corruption or misunderstanding).

The above versions agree that the Buddha was willing to teach what he knew even without expecting nonBuddhist wanderers to give up their teacher and instead place him in that position. Another passage reports a related attitude in relation to a wealthy and influential householder who had just told the Buddha that from then onward he considered himself a Buddhist lay disciple. The parallel versions of this encounter agree in reporting that the Buddha immediately requested that this householder continue to support the Jains as he had done earlier when still considering himself their disciple (MN 56 and $\mathrm{MA}$ 133).

These episodes provide a remarkable contrast to the ancient Indian notion of submission and obedience owed to one's teacher, the guru. Pointing this out is not to take the position that the Buddha did not function as an authority or did not demand respect from his disciples, in particular when it comes to the need for monastics to follow his rules and regulations (MN 65 and MĀ 194). The point is only that, when assuming the traditional role of a teacher in the ancient Indian setting, the Buddha is depicted as doing so in an open and flexible manner that left considerable room for personal freedom and uninhibited investigation. 


\section{Mindful Self-Reliance}

A comparable tendency to encourage self-reliance emerges from an instruction reportedly given by the Buddha when his chief disciple Sāriputta had just passed away. The instruction takes the following form:

Therefore, Ānanda, you should dwell as an island to yourself, with yourself as a refuge, with no other refuge, with the Dharma as your island, with the Dharma as your refuge, with no other refuge. Ānanda, and how does a monastic dwell as an island to themselves, with themselves as a refuge, with no other refuge, with the Dharma as their island, with the Dharma as their refuge, with no other refuge? Here, Ānanda, a monastic dwells contemplating the body in regard to the body, diligent, clearly knowing, and mindful, free from greed and sadness with regard to the world ... feeling tones ... mind ... dwells contemplating dharmas in regard to dharmas, diligent, clearly knowing, and mindful, free from greed and sadness with regard to the world.

(SN 47.13: tasmātihānanda attadīpā viharatha

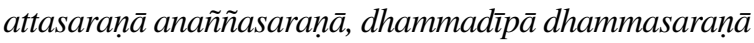

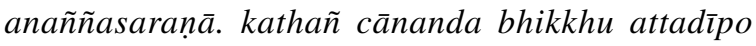
viharati attasaraṇo anañnasaraṇo, dhammadīpo dhammasarano anañ̃nasarano? idhānanda bhikkhu kāye kāyānupassī viharati ātāpi sampajāno satimā, vineyya loke abhijjhādomanassam; vedanāsu pe citte pe dhammesu dhammānupassī viharati ātā̄p̄ sampajāno satimā, vineyya loke abhijjhādomanassam).

"Therefore, Ānanda, you should make yourself an island by relying on yourself, you should make the Dharma your island by relying on the Dharma; you should make yourself no other island, no other reliance." Ānanda said to the Buddha: "Blessed One, how does one have oneself as an island by relying on oneself? How does one have the Dharma as an island by relying on the Dharma? How does one have no other island, no other reliance?" The Buddha said to Ānanda: "[This takes place] if a monastic establishes mindfulness by contemplating the body [in regard to] the body, with diligent effort, right knowing, and right mindfulness, overcoming greed and sadness in the world, and in the same way the body externally and the body internally and externally ... feeling tones ... the mind ... and establishes mindfulness by contemplating dharmas [in regard to] dharmas.

(SĀ 638: 阿難, 當作自洲而自依, 當作法洲而法依, 當作不異洲不異依. 阿難白佛: 世尊, 云何自洲以自 依? 云何法洲以法依? 云何不異洲不異依? 佛告阿 難: 若比丘身身觀念處, 精勤方便, 正智, 正念, 調伏 世間貪憂. 如是外身, 內外身, 受, 心, 法法觀念處).
Alongside some minor differences, the parallels agree on the main instruction to encourage self-reliance. The key tool for putting that into practice can be found in the formal cultivation of mindfulness. The above type of instruction is a recurrent one in the early discourses, given reportedly by the Buddha also in relation to his own impending passing away (Anālayo 2015). This is particularly noteworthy, as the Buddha is on record for not appointing anyone as his successor ( $\mathrm{MN}$ 108 and $M \bar{A}$ 145). Instead, the teachings were to take the place left vacant once he had passed away, and here in particular in the form of the four establishments of mindfulness.

In line with the references surveyed above, regarding the Buddha's open and flexible attitude toward taking up the role of the teacher, this type of instruction highlights the importance of turning to mindfulness as one's main "refuge," a term with considerable ramifications in early and later Buddhist thought, thereby offering a direct and practical approach for building up self-reliance. Such self-reliance also throws into relief the centrality of mindfulness meditation in early Buddhist thought.

Although in the above setting of serving as a form of refuge, the main concern can safely be assumed to be with the soteriological function of mindfulness as a key quality for progress to awakening, such concern does not exhaust the various roles and functions of mindfulness in early Buddhist thought. This can be seen in the report that the Buddha gave instructions on mindful eating to an overweight ancient Indian king, so as to assist the latter in reducing his weight (SN 3.13, SĀ 1150, and $\mathrm{SA}^{2}$ 73; Anālayo 2018a and 2020a, pp. 175-181).

Among an otherwise overarching soteriological orientation of mindfulness in early Buddhist thought, this passage constitutes a precedent for the employment of mindfulness aimed at health benefits. In fact, it may well be the earliest recorded instance of instructions on mindfulness for such purposes. This in turn makes early Buddhist thought, together with all the other rich Buddhist traditions that grew from it, a relevant partner for an ongoing dialog with those involved in the clinical employment of mindfulness.

Abbreviations AN: Ánguttara-nikāya; DĀ: Dīrgha-āgama (T 1); DN: D̄̄gha-nikāya; EĀ: Ekottarika-āgama (T 125); Jā: Jātaka; MĀ: Madhyama-āgama (T 26); Mil: Milindapañha; MN: Majjhima-nikāya; SĀ: Samyukta-āgama (T 99); SĀ²: Samyuktaāgama (T 100); SN: Samyutta-nikāya; T: Taishō edition; Up: Abhidharmakośopāyikā-țīka

Funding Open Access funding enabled and organized by Projekt DEAL. 


\section{Declarations}

Ethical Approval This article does not contain any studies performed by the author with human participants or animals.

Competing Interests The author declares no competing interests.

Open Access This article is licensed under a Creative Commons Attribution 4.0 International License, which permits use, sharing, adaptation, distribution and reproduction in any medium or format, as long as you give appropriate credit to the original author(s) and the source, provide a link to the Creative Commons licence, and indicate if changes were made. The images or other third party material in this article are included in the article's Creative Commons licence, unless indicated otherwise in a credit line to the material. If material is not included in the article's Creative Commons licence and your intended use is not permitted by statutory regulation or exceeds the permitted use, you will need to obtain permission directly from the copyright holder. To view a copy of this licence, visit http://creativecommons.org/licenses/by/4.0/.

\section{References}

Anālayo, Bh. (2006). The Buddha and omniscience. Indian International Journal of Buddhist Studies, 7, 1-20.

Anālayo, Bh. (2010a). The genesis of the Bodhisattva ideal. Hamburg: Hamburg University Press.

Anālayo, Bh. (2010b). The scope of free inquiry, according to the Vīmaṃsaka-sutta and its Madhyama-āgama parallel. Rivista Di Studi Sudasiatici, 4, 7-20.

Anālayo, Bh. (2012). The historical value of the Pāli discourses. IndoIranian Journal, 55, 223-253. https://doi.org/10.1163/00197 2412 X620187

Anālayo, Bh. (2014). The dawn of Abhidharma. Hamburg: Hamburg University Press.

Anālayo, Bh. (2015). Healing in early Buddhism. Buddhist Studies Review, 32(1), 19-33. https://doi.org/10.1558/bsrv.v32i1.28962

Anālayo, Bh. (2016a). Levitation in early Buddhist discourse. Journal of the Oxford Centre for Buddhist Studies, 10, 11-26.

Anālayo, Bh. (2016b). The Vessantara-Jātaka and Mūlasarvāstivāda Vinaya narrative. Journal of the Oxford Centre for Buddhist Studies, 11, 11-37.
Anālayo, Bh. (2017a). Buddhapada and the Bodhisattva path. Bochum: Projektverlag.

Anālayo, Bh. (2017b). A meditator's life of the Buddha, based on the early discourses. Cambridge: Windhorse Publications.

Anālayo, Bh. (2018a). Overeating and mindfulness in ancient India. Mindfulness, 9(5), 1648-1654. https://doi.org/10.1007/ s12671-018-1009-x

Anālayo, Bh. (2018b). Rebirth in early Buddhism and current research. Boston: Wisdom Publications.

Anālayo, Bh. (2019a). In the seen just the seen: Mindfulness and the construction of experience. Mindfulness, 10(1), 179-184. https:// doi.org/10.1007/s12671-018-1042-9

Anālayo, Bh. (2019b). Rebirth and the West. Insight Journal, 45, 55-64.

Anālayo, Bh. (2020a). Mindfulness in early Buddhism, characteristics and functions. Cambridge: Windhorse Publications.

Anālayo, Bh. (2020b). The Tevijjavacchagotta-sutta and the Anupadasutta in relation to the emergence of Abhidharma thought. Journal of the Centre for Buddhist Studies, 17, 21-33.

Anālayo, Bh. (2021). Overcoming fear by recollecting the Buddha: His role in early Buddhist texts. Mindfulness, 12(3), 594-603. https:// doi.org/10.1007/s12671-020-01518-z

Cabezón, J. I. (2003). Buddhism and science: On the nature of the dialogue. In B. A. Wallace (Ed.), Buddhism and science: Breaking new ground (pp. 35-68). New York: Columbia University Press.

Dietz, S. (2007). The Saptasūryodayasūtra. In K. Klaus and J.-U. Hartmann (ed.) Indica et Tibetica 65, Festschrift für Michael Hahn zum 65. Geburtstag von Freunden und Schülern überreicht (pp. 93-112). Wien: Arbeitskreis für tibetische und buddhistische Studien, Universität Wien.

Dumont, L. (1962). The conception of kingship in ancient India. Contributions to Indian Sociology, 6, 48-77.

Lopez, D. S., Jr. (2008). Buddhism and science: A guide for the perplexed. Chicago: The University of Chicago Press.

Rhys Davids, T. W. (1903/1997). Buddhist India. Delhi: Motilal Banarsidass.

Thompson, E. (2020). Why I am not a Buddhist. New Haven: Yale University Press.

Publisher's Note Springer Nature remains neutral with regard to jurisdictional claims in published maps and institutional affiliations. 